\title{
Fiscal Sustainability in the Caribbean: An Econometric Analysis
}

\author{
Jeetendra Khadan ${ }^{1, *}$ \\ ${ }^{1}$ Inter-American Development Bank, Washington DC, U.S.A. \\ *Corresponding author: Inter-American Development Bank, Washington DC, U.S.A. E-mail: \\ jeetendra.khadan@gmail.com
}

Received: April 21, 2019 Accepted: May 22, 2019 Published: June 24, 2019

doi: 10.5296/rae.v11i2.14697 URL: https://doi.org/10.5296/rae.v11i2.14697

\begin{abstract}
Many countries in the Caribbean have been grappling with persistent fiscal imbalances and rising debt levels. The average debt to GDP ratio in the Caribbean in 2017 was 76.6 percent, higher than the negative debt-growth threshold of 60 percent of GDP. Also, the average fiscal deficit as a percent of GDP was 2.8 percent, but with significant heterogeneity across countries ranging from 0.5 percent to 11 percent. Using the inter-temporal budget constraint framework and various panel data econometric estimators, this article examines the issue of fiscal sustainability for a group of 10 Caribbean countries over the period 1991-2017. The evidence from panel cointegration models of government revenue and expenditure shows that past fiscal behavior is "weakly" sustainable. The "weak sustainability" finding is reinforced by evidence from an extended fiscal reaction function which showed that the primary balance improves by about 0.02 for every 1 percentage point increase in the debt ratio.
\end{abstract}

Keywords: fiscal sustainability, Caribbean, panel cointegration, intertemporal budget constraint

JEL: C32, E62, H62, H63 


\section{Introduction}

The issue of fiscal sustainability has received increasing attention in Caribbean countries following the 2008-2009 global financial crisis and the more recent commodity price shocks of 2014-2015. These exogeneous shocks combined with natural hazards such as tropical storms and floods, inadequate policy responses and limited institutional arrangements to guide corrective measures have contributed to persistent budgetary imbalances leading to increasing debt ratios in some Caribbean countries (see Acevedo, Cebotari, and Turner-Jones, 2013; Alleyne, Ötker, Ramakrishnan, and Srinivasan, 2017; Fajgenbaum and Loser, 2018; Samaké and Spatafora, 2012; Villafuerte, Lopez-Murphy, and Ossowski, 2010; Koetsier, 2017; Medina, 2010; Ramirez and Wright, 2017). The majority of countries have debt ratios that are above the negative debt-growth threshold of 60 percent of GDP as suggested by Greenidge et al. (2012): the simple average of the general government debt to GDP ratio for the Caribbean increased from 66.4 percent in 2008 to 76.6 percent in 2017, ranging from 42 percent to 157 percent for countries in the region. Moreover, fiscal deficits have also been increasing, rising from an average of 1.8 percent of GDP in 2008 to 2.8 percent of GDP, and ranging from 0.5 percent of GDP to 11 percent of GDP. Indeed, a few Caribbean countries are amongst some of the most indebted in the world and the region is typically referred to by the moniker of high debt-low growth (Acevedo, Cebotari, and Turner-Jones, 2013; Alleyne, 2014). High levels of debt are usually associated with downward pressure on economic growth and combined with low credit ratings can trigger increases in long term interest rates for sovereign bonds and increased interest payments on debt, thus placing countries into a vicious unsustainable cycle of increasing debt and interest payments (see Greenidge et al. 2012 and IDB, 2016). Therefore, from a macroeconomic stability perspective it is important for countries to pursue fiscal policies that are sustainable in the long run.

The concept of fiscal sustainability being tested for Caribbean countries in this paper is based on the inter-temporal budget constraint of Hamilton and Flavin (1986) which states that the market value of public debt must be equal to the present value of all discounted future budget surpluses. This approach involves testing for the existence of unit roots in government debt and budget deficits and/or investigating the series of government revenues and expenditures for the presence of cointegration. Some empirical studies that have used this approach for the United States, European countries and Latin America include Quintos (1995), Hakkio and Rush (1991), Afonso (2005) and Kirchgaessner and Prohl (2008). While most of the earlier work focused on the stationarity of budget deficit and public debt, this paper follows the approach used in more recent works that has moved towards testing for the presence of cointegration between government revenues and expenditures (see Khadan and Deonarine, 2019; Westerlund and Prohl, 2010; Afonso and Jalles, 2012; Claeys, 2007; Ehrhart and Llorca, 2007). This paper also investigates fiscal sustainability through fiscal reaction functions which examine how primary balances adjust to rising debt levels in a panel setting following the approach of Bohn (1998), while allowing for the control of other political and economic determinants of the primary balance.

Caribbean countries represent an interesting case study for an assessment of the fiscal sustainability hypothesis given their current fiscal and debt situation and the potential fiscal 
risks derived from their structural features such as small open economies, vulnerability to commodity price shocks and natural hazards and weak economic institutions, all of which help to exacerbate the impact of shocks on fiscal performance and debt. In this regard, the main contribution of this paper is to fill an empirical gap by applying recent advances in panel unit root testing and cointegration to obtain a deeper understanding of fiscal sustainability issues in the Caribbean. Such evidence has important implications for policy makers as it relates to long-term fiscal sustainability. The remainder of this paper is organized as follows. Section 2 gives a brief description of the theoretical model of fiscal sustainability. The data and empirical results are reported in section 3 and while Section 4 concludes the paper.

\section{Theoretical Framework}

Fiscal sustainability refers the ability of Governments to fulfil the inter-temporal budget constraint (IBC). The IBC is based on the idea that Governments are implicitly promising to post sufficient budget surpluses in the future to cover the accumulated debt and interest payments associated with fiscal deficits in current periods (Baglioni and Cherubini, 1993). In this regard, fiscal policy is considered sustainable if the IBC holds in present value terms, that is, the current debt levels in an economy should be compensated by the present value of future fiscal surpluses.

The basic mechanics of the present value borrowing constraint (PVBC) and how it can be tested empirically is outlined below, drawing from several papers (see for example Afonso and Jalles, 2012; Afonso and Rault, 2009; Claeys, 2007; Ehrhart and Llorca, 2007, Ehrhart and Llorca, 2017; Westerlund and Prohl, 2010). The theoretical framework of fiscal sustainability can be explained algebraically by starting with the government's flow budget constraint at time $\mathrm{t}:$

$$
G_{t}+\left(1+r_{t}\right) B_{t-1}=R_{t}+B_{t}
$$

Where $B_{t}$ is the stock of public debt, $R_{t}$ is the government revenue, $G_{t}$ is the primary government expenditure (government expenditure excluding interest payments), and $r_{t}$ is the real interest rate payable on public debt. The intertemporal budget constraint is derived by rewriting equation (1) for subsequent periods and solving recursively to yield:

$$
B_{t}=\sum_{s=1}^{\infty} \frac{R_{t+s}-G_{t+s}}{\prod_{j=1}^{s}\left(1+r_{t+j}\right)}+\lim _{s \rightarrow \infty} \prod_{j=1}^{s} \frac{B_{t+s}}{\left(1+r_{t+j}\right)}
$$

The formulation in equation (2) implies that when the $\lim _{s \rightarrow \infty} \prod_{j=1}^{s} \frac{B_{t+s}}{\left(1+r_{t+j}\right)}=0$, the present value of public debt at time $t$ will be equal to the present value of future primary surpluses. To obtain an appropriate specification for empirical testing, it is assumed that the real interest rate is stationary with mean $r$, and defining $E_{t}=G_{t}+\left(r_{t}-r\right) B_{t-1}$ the present value borrowing constraint (PVBC) becomes: 


$$
B_{t-1}=\sum_{s=0}^{\infty} \frac{1}{(1+r)^{s+1}}\left(R_{t+s}-E_{t+s}\right)+\lim _{s \rightarrow \infty} \frac{B_{t+s}}{\left(1+r_{t+j}\right)^{s+1}}
$$

From equation 3, sustainable fiscal policy requires that the present value of the stock of public debt goes to zero in infinity, thus constraining debt to grow no faster than that of the real interest rate and thereby imposing the no-Ponzi scheme condition.

The PVBC can be expressed as ratio's where $y_{t}$ is the real GDP growth rate and $Y_{t}$ is the nominal GDP:

$$
b_{t-1}=\sum_{s=0}^{\infty}\left(\frac{1+y}{1+r}\right)^{s+1}\left(\rho_{t+s}-e_{t+s}\right)+\lim _{s \rightarrow \infty} b_{t+s}\left(\frac{1+y}{1+r}\right)^{s+1}
$$

$b_{t}=\frac{B_{t}}{Y_{t}}, e_{t}=\frac{E_{t}}{Y_{t}}$, and $\rho_{t}=\frac{R_{t}}{Y_{t}}$. When $r>y$, the solvency condition $\lim _{s \rightarrow \infty} b_{t+s}\left(\frac{1+y}{1+r}\right)^{s+1}=0$ is needed to bound the growth of public debt, implying that the growth of the debt-GDP ratio should be less than $\left(\frac{1+y}{1+r}\right)^{s+1}$ (see Afonso and Rault, 2009).

Combining equation 3 and the auxiliary equation $E_{t}=G_{t}+\left(r_{t}-r\right) B_{t-1}$ and defining of $G G_{t}=G_{t}+r B_{t-1}$ the intertemporal budget constraint can be written as:

$$
G G_{t}-R_{t}=\sum_{s=0}^{\infty} \frac{1}{(1+r)^{s-1}}\left(\Delta R_{t+s}-\Delta E_{t+s}\right)+\lim _{s \rightarrow \infty} \frac{B_{t+s}}{(1+r)^{s+1}}
$$

For the no-Ponzi games condition to hold, the variables $G G_{t}$ and $R_{t}$ must be cointegrated of order one. An empirical test for fiscal sustainability is then obtained by estimating the following cointegration regression:

$$
R_{t}=\alpha+\beta G G_{t}+u_{t}
$$

\section{Estimation Strategy and Empirical Results}

The approach used to estimate the long run relationship between government expenditure and revenue involve four steps: (i) testing for cross sectional independence, (ii) testing for stationarity, (iii) testing for cointegration and (iv) estimation of the panel cointegrating vector. This section presents the empirical unit root and cointegration test results and the results of the estimated cointegration vector using different methods.

\subsection{Data}

The analysis is conducted for 10 Caribbean countries using annual data for the period 1991 to 2017. The countries included in the panel are The Bahamas, Barbados, Dominica, Grenada, Guyana, Jamaica, St. Kitts and Nevis, Suriname, Trinidad and Tobago and St. Vincent and the Grenadines. The fiscal variables are defined as general government revenue and general government expenditure. Both fiscal variables are expressed as a percentage of nominal GDP and sourced from the International Monetary Fund's World Economic Outlook, October 2018, 
Central Banks databases and IMF Article IV reports.

\subsection{Cross-sectional Dependence}

Cross-section independence refers to the contemporaneous correlation among countries that can be caused by factors such as common global shocks like commodity price shocks which impact all individuals (although at varying degrees), decisions of economic agents that can lead to interdependence among individuals, market integration processes, and globalization (Banerjee and Carrion-i-Silvestre, 2017; Hsiao, Pesaran and Pick, 2012). One important drawback of the cross-sectional independence assumption is that it is often restrictive and somewhat unrealistic in macroeconomic applications leading to strong size distortions and limited power in testing for unit roots (see for example Banerjee et al., 2004; 2005; Hurlin an Migon, 2007; Lyhagen, 2008; O’Connell, 1998; Phillips and Sul, 2003). If observations are dependent across countries, then panel unit root tests based on the assumption of cross sectional independence may be inappropriate. For this reason, panel unit root tests are classified into two groups: first-generation panel unit root tests and second-generation panel unit root tests, with the main difference between them being that first-generation tests assume cross-sectional independence while second-generation tests accounts for cross-sectional dependence across panel units (see Hurlin an Migon, 2007). Thus, as a first step in ascertaining the properties of the fiscal variables a test for the presence of cross-country dependence is performed by applying the Pesaran (2004) cross sectional dependence (CD) test which tests a null hypothesis of cross-section independence. The CD test statistic is formulated as follows:

$$
C D=\sqrt{\frac{2 T}{N(N-1)}}\left(\sum_{i=1}^{N} \sum_{j=i+1}^{N} \hat{\rho}_{i j}\right)
$$

Where $\hat{\rho}_{i j}$ is the sample estimate of the pairwise correlation of residuals from an Augmented Dickey Fuller (ADF) type regression, $\mathrm{N}$ is the cross-sectional dimension and $\mathrm{T}$ is the panel's time dimension (Pesaran 2004). The CD statistic is normally distributed under the null hypothesis of cross-sectional independence and is also robust to the presence of single and multiple structural breaks in the slope coefficients and the error variances (Pesaran, 2004). The results from the CD test are reported in Table 1 and shows that the null hypothesis of cross-sectional independence is strongly rejected for both fiscal variables. In addition, the average absolute cross-section correlation coefficients $\left|p_{i j}\right|$ is somewhat high at 0.3 for government revenues and 0.38 for government expenditures. Hence, the evidence suggests the presence of cross-sectional dependence for a panel of Caribbean countries.

Table 1. Pesaran (2004) Tests for Cross Section Independence Caribbean Countries

\begin{tabular}{lcccc}
\hline $\begin{array}{c}\text { Variables (in \% of } \\
\text { GDP) }\end{array}$ & CD-test & P-value & Avg. (pij) & Avg. $\mid($ pij) $\mid$ \\
\hline Revenue & 5.53 & 0.00 & 0.16 & 0.30 \\
Expenditure & 8.01 & 0.00 & 0.23 & 0.38 \\
\hline
\end{tabular}

Source: Author's estimates. 


\subsection{Panel Unit Root Tests}

With the presence of cross-sectional dependence, this section employs Pesaran (2007) second generation panel unit root test to examine the properties of the fiscal variables. The Pesaran test augments the standard ADF regressions with the cross-section average of lagged levels and first differences as the common factor to filter out the cross-sectional dependence (Pesaran, 2007). The cross-sectionally augmented IPS (CIPS) test statistic is based on the average of individual cross-sectionally ADF (CADF) statistic following the procedure in the Im, Pesaran and Shin (2003) test which yields:

$$
\operatorname{CIPS}(N, T)=t-\text { bar }=N^{-1} \sum_{i=1}^{N} t_{i}(N, T)
$$

Where $t_{i}(N, T)$ is the cross-sectionally ADF (CADF) statistic for the $i^{\text {th }}$ cross-section in the panel and is provided by the $t$-ratio of the least squares estimate of the $b_{i}\left(\widehat{b}_{\imath}\right)$ coefficient obtained from the CADF regression below:

$$
\Delta y_{i t}=\alpha_{i}+b_{i} y_{i, t-1}+c_{i} \bar{y}_{t-1}+d_{i} \Delta \bar{y}_{t}+e_{i t}
$$

It tests a null hypothesis of non-stationarity under a non-standard distribution where critical values are computed for different combinations of $\mathrm{N}$ and $\mathrm{T}$. The test has been shown to have satisfactory size and power even when $\mathrm{N}$ and $\mathrm{T}$ have small values, as in our case (Pesaran 2007). For comparison, four first-generation panel unit tests are employed to examine the fiscal variables: Breitung (2000), Im Pesaran and Shin (IPS, 2003), Levin Lin and Chu (LLC, 2002), and Hadri (2000). The LLC, IPS and Breitung statistics all tests a null hypothesis that the variable has a unit root. Breitung (2000) showed that the power of the LLC and IPS test statistics are sensitive to the inclusion of deterministic components such as individual specific trends and proposed a modification to the LLC approach - the Breitung test - to address this shortcoming. The Breitung test statistic tests a null hypothesis of a unit root and an alternative hypothesis that the panel series is stationary. It differs from the LLC test in the way it controls for serial correlation: the LLC uses additional lags of the dependent variable while Breitung allows for pre-whitening of the series prior to the computation of the test statistic. The Hadri residual-based Lagrange multiplier test, on the other hand, builds on the Kwiatkowski-Phillips-Schmidt Shin test (KPSS) from time series and examines a null hypothesis that the series follows a stationary process around a deterministic trend (Kwiatkowski et al., 1992). The null hypothesis of the Hadri test is that each series in the panel is stationary (Hadri, 2000), while the alternative hypothesis is that the panel has a unit root.

The results are reported in Table 2. The Pesaran (2007) CIPS test is applied to both variables with both constant and trend deterministics, and a maximum of 5 lags for each panel unit in the model. The critical values of the CIPS test with constant and trend in levels are $-3.3(1 \%)$, $-2.94(5 \%)$ and $-3.3(10 \%)$ and in first differences are $-3.1(1 \%),-2.82(5 \%)$ and $-2.67(10 \%)$. The CIPS test indicates that the ratios of government revenues and government expenditures are not stationary in levels at the 5 percent level of statistical significance. Applying the CIPS test to the first difference of the fiscal variables leads to a rejection of the null hypothesis of 
non-stationarity at all levels of statistical significance, implying that the variables are integrated to the order of one. The application of first generation tests also concludes the presence of a unit root for both fiscal variables (see Table 2).

Table 2. Panel Unit Root Test for Caribbean Countries

\begin{tabular}{|c|c|c|c|c|c|}
\hline & $\begin{array}{c}\text { LLC } \\
\left(t^{*} \text {-stat) }\right.\end{array}$ & $\begin{array}{l}\text { Breitun } \\
\mathrm{g} \text { (t-stat) }\end{array}$ & $\begin{array}{l}\text { Hadri } \\
\text { (z-stat) }\end{array}$ & $\begin{array}{c}\text { IPS } \\
\text { (w-stat) }\end{array}$ & $\begin{array}{c}\text { Pesaran (2007) } \\
(\mathrm{z} \text {-stat })^{*}\end{array}$ \\
\hline \multicolumn{6}{|c|}{ Levels } \\
\hline Expenditure & $\begin{array}{c}-0.23 \\
{[0.41]}\end{array}$ & $\begin{array}{c}-0.58 \\
{[0.28]}\end{array}$ & $\begin{array}{c}7.66 \\
{[0.00]}\end{array}$ & $\begin{array}{l}-0.28 \\
{[0.39]}\end{array}$ & -2.90 \\
\hline Revenue & $\begin{array}{c}-0.77 \\
{[0.22]}\end{array}$ & $\begin{array}{c}-1.3 \\
{[0.10]}\end{array}$ & $\begin{array}{c}9.63 \\
{[0.00]} \\
\end{array}$ & $\begin{array}{c}-1.94 \\
{[0.03]}\end{array}$ & -2.60 \\
\hline \multicolumn{6}{|c|}{ First differences } \\
\hline$\Delta$ Expenditure & $\begin{array}{l}-12.2 \\
{[0.00]}\end{array}$ & $\begin{array}{c}-3.03 \\
{[0.00]}\end{array}$ & $\begin{array}{c}0.89 \\
{[0.19]}\end{array}$ & $\begin{array}{l}-12.5 \\
{[0.00]}\end{array}$ & -5.55 \\
\hline$\Delta$ Revenue & $\begin{array}{r}-10.15 \\
{[0.00]} \\
\end{array}$ & $\begin{array}{c}-1.6 \\
{[0.05]}\end{array}$ & $\begin{array}{c}-0.6 \\
{[0.73]}\end{array}$ & $\begin{array}{l}-12.04 \\
{[0.00]}\end{array}$ & -5.36 \\
\hline
\end{tabular}

Source: Author's estimates.

Notes: Values in parenthesis denote p-values. $\Delta$ represents first difference of the variables. *** Statistically significant at the $1 \%$ level. ** Statistically significant at the $5 \%$ level. * Statistically significant at the $10 \%$ level.

\subsection{Panel Cointegration Test}

Having established the panel stationarity properties of the fiscal variables, this section proceeds to test for the existence of a long-run equilibrium relationship using panel cointegration tests. Panel cointegration testing can be applied to the non-stationary fiscal variables by using either residual based tests of Pedroni $(1999,2004)$ and Kao (1999) or the error correction test of Westerlund (2007).

Pedroni's $(1999,2004)$ cointegration tests is based on the Engle and Granger (1987) approach of time series analysis and tests a null hypothesis of no cointegration in non-stationary panels. The Pedroni tests consists of seven panel cointegration statistics that are obtained from the residuals of the static long run regression and is separated into two groups: (i) panel statistics tests (panel variance statistics, panel $p$-statistics, panel PP-statistics, and panel ADF-statistics) and (ii) group statistics tests (group $p$-statistics, group PP-statistics and group ADF-statistics). The panel statistics tests assume homogeneity of the autoregressive term while the group statistics tests allow for heterogeneity of the autoregressive term. In our application, only the group statistics that allow for heterogeneity of the autoregressive term is presented in Table 3. Pedroni (1999) provided critical values for these tests which can include individual short run 
dynamics, specific slope coefficients, deterministic trends and individual specific fixed effects. Kao (1999) also proposed a residual-based test that is similar to the Pedroni test and tests a null hypothesis of no cointegration, but unlike the Pedroni test it is based on the assumption of homogeneity across individual units. Kao's panel test is found to have higher power than the Pedroni test when the number of observations is small. Both residual-based tests assume the presence of a single cointegrating vector. However, one of the criticisms of the residual-based tests is their failure to reject the no-cointegration null hypothesis, even when theory strongly suggest that they should. One of the explanation for this is that most residual based tests have a common factor restriction that requires the long-run parameters of variables in their levels to be equal their short-run parameters in first differences, which causes a significant loss of power in residual based tests. Moreover, Kao and Pedroni tests assume cross-section independence among the units of the panel (Banerjee and Carrion-i-Silvestre, 2017), which is not consistent with the properties of both fiscal variables for the panel of Caribbean countries as established in the previous section.

The Westerlund (2007) panel cointegration test overcome the shortcomings of the residual -based tests as it does not impose a common factor restriction. Westerlund proposed an error correction based test which consist of four panel cointegration tests that allow for unit-specific short-run dynamics, unit-specific trend and slope parameters, and also treats with the issue of cross sectional dependence. First, Westerlund considered the following data-generating process for the error correction tests:

$$
\Delta y_{i t}=\delta_{i}^{\prime} d_{t}+\alpha_{i}\left(y_{i, t-1}-\beta_{i}^{\prime} x_{i, t-1}\right)+\sum_{j=1}^{p_{i}} \alpha_{i j} \Delta y_{i, t-j}+\sum_{j=0}^{p_{i}} \gamma_{i j} \Delta x_{i, t-j}+e_{i t}
$$

Where $t$ and $i$ represent the time-series and cross-sectional dimensions respectively, $d_{t}$ represents the deterministic components with $\delta_{i}^{\prime}$ containing the respective parameters, $\alpha_{i}$ is the error-correction term. Rewriting equation 10 below with $\lambda_{i}^{\prime}=-\alpha_{i} \beta_{i}^{\prime}$ gives:

$$
\Delta y_{i t}=\delta_{i}^{\prime} d_{t}+\alpha_{i} y_{i, t-1}+\lambda_{i}^{\prime} x_{i, t-1}+\sum_{j=1}^{p_{i}} \alpha_{i j} \Delta y_{i, t-j}+\sum_{j=-q_{i}}^{p_{i}} \gamma_{i j} \Delta x_{i, t-j}+u_{i t}
$$

The parameter $\alpha_{i}$ provides information on the speed at which the system reverts to the equilibrium relationship $y_{i, t-1}-\beta_{i}^{\prime} x_{i, t-1}$ after a shock. In this set-up, error correction occurs if $\alpha_{i}<0$ which implies that the variables $x_{i t}$ and $y_{i t}$ are cointegrated. However, if $\alpha_{i}=0$ there is no error correction and no cointegration, which defines the null hypothesis as $H_{0}: \alpha_{i}=0$. On the other hand, the alternative hypothesis depends in the homogeneity assumption of $\alpha_{i}$ for which there are two sets of tests: (i) group-mean tests that do not require equality of $\alpha_{i} s$ for which the alternative hypothesis is $H_{1}^{G}: \alpha_{i}<0$, and (ii) panel tests which assume that $\alpha_{i}$ is equal for all cross-sections and yields an alternative hypothesis of $H_{1}^{P}: \alpha_{i}=\alpha<0$. Moreover, the Westerlund tests treats with the presence of cross-sectional dependence through bootstrapping.

The results from the three cointegration tests provides strong evidence of the cointegration between government revenues and government expenditures (Table 3). The three group 
statistics of the Pedroni tests (Modified Phillips-Perron, Phillips-Perron and Augmented Dickey-Fuller) strongly rejects the null hypothesis of no-cointegration. Of the five Kao test statistics, the modified Dickey-Fuller test, the unadjusted modified Dickey and Fuller test and the unadjusted Dickey-Fuller test rejected the null hypothesis of no-cointegration at the 5 percent level of significance and the Dickey-Fuller and Augmented Dickey-Fuller rejected the null hypothesis of no-cointegration at the 10 percent level of significance. Also, the robust P-values of the Westerlund tests show a strong rejection of the null hypothesis of no-cointegration for both the panel and group mean tests in Table 3.

Table 3. Panel Cointegration Tests for Caribbean Countries

\begin{tabular}{|c|c|c|c|c|}
\hline & & & Statistic & P-value \\
\hline \multicolumn{5}{|c|}{ Pedroni test for cointegration } \\
\hline \multicolumn{3}{|c|}{ Modified Phillips-Perron $t$} & -2.12 & 0.02 \\
\hline \multicolumn{3}{|c|}{ Phillips-Perron t } & -3.37 & 0.00 \\
\hline \multicolumn{3}{|c|}{ Augmented Dickey-Fuller t } & -3.78 & 0.00 \\
\hline \multicolumn{5}{|c|}{ Kao test for cointegration } \\
\hline \multicolumn{3}{|c|}{ Modified Dickey-Fuller t } & -2.12 & 0.02 \\
\hline \multicolumn{3}{|c|}{ Dickey-Fuller t } & -1.56 & 0.06 \\
\hline \multicolumn{3}{|c|}{ Augmented Dickey-Fuller t } & 1.47 & 0.07 \\
\hline \multicolumn{3}{|c|}{$\begin{array}{l}\text { Unadjusted modified Dickey } \\
\text { Fuller }\end{array}$} & -4.33 & 0.00 \\
\hline \multicolumn{3}{|c|}{ Unadjusted Dickey-Fuller t } & -2.49 & 0.01 \\
\hline \multicolumn{5}{|c|}{$\begin{array}{l}\text { Westerlund ECM panel cointegration tests } \\
\end{array}$} \\
\hline & Value & Z-value & P-value & Robust P-value \\
\hline $\mathrm{Gt}_{\mathrm{t}}$ & -1.95 & -2.97 & 0.00 & 0.00 \\
\hline $\mathrm{G}_{\mathrm{a}}$ & -6.49 & -1.87 & 0.03 & 0.01 \\
\hline $\mathrm{Pt}$ & -6.18 & -3.91 & 0.00 & 0.00 \\
\hline $\mathrm{Pa}$ & -5.42 & -4.79 & 0.00 & 0.00 \\
\hline
\end{tabular}

Source: Author's estimates.

Note: 1000 bootstrap replications are used for to obtain Robust P-value in the Westerlund cointegration tests. The bootstrapped versions of the error-correction tests are robust to the presence of cross-sectional dependence.

\subsection{Evidence of Weak Fiscal Sustainability}

This section estimates the long-run parameters and short-run adjustments coefficients associated with the cointegration relationship of the fiscal variables. Three panel cointegration estimation techniques - mean group (MG) estimator, pooled mean group (PMG) estimator and dynamic fixed effects (DFE) model are employed. Pesaran and Smith (1995) introduced the MG estimator which estimates separate regressions for each cross-section in 
the panel and computes a simple arithmetic average of country-specific long run coefficients. The MG estimator allows for all parameters including the intercepts, slope coefficients, and error variances to differ across groups. Although the MG estimator yields consistent estimates of the average of the parameters, it is highly sensitive to outliers especially for small $\mathrm{N}$ samples and does not consider the fact that certain parameters may be the same across groups (Pesaran and Smith, 1995; Pesaran, Shin and Smith, 1999). Pesaran, Shin and Smith (1999) provided an alternative approach-PMG estimator - to the MG estimator which involves a combination of pooling and averaging of coefficients. The PMG estimator allows for the short run coefficients, the intercepts and error variances to be heterogeneous across groups, while the long-run coefficients are restricted to be the same. The short run adjustment is allowed to be country specific to reflect the different impact of vulnerabilities to financial shocks, external shocks, monetary policy shock, stabilization policies among other factors across countries (Samargandi, Fidrmuc, and Ghosh, 2014). In addition to the MG and PMG, the DFE model which is based on pooling over cross-sections where the slopes are fixed, and the intercepts vary across countries is employed. However, Pesaran and Smith (1995) noted that the DFE estimates are affected by a potentially serious heterogeneity bias, especially in small samples.

In this regard, a Hausman test is employed to determine whether the homogeneity assumption of the long-run parameters hold (see also Pesaran et al., 1999; Hausman, 1978). The Hausman test examines the efficiency of the PGM estimators in relation to the MG and DFE estimators by testing a null hypothesis that the difference between the PMG and MG estimation or the PMG and DFE estimation is not systematic. The results show that the PMG estimator is more efficient under the null hypothesis and is preferred over the MG and DFE estimators (see Table 4). Moreover, the error correction term $\hat{\alpha}$ has the correct sign and is statistically significant at all conventional levels of statistical significance. This reinforces the evidence of a long-run or cointegration relationship between the two fiscal variables. The error correction term is estimated to be -0.392 under the PMG estimator indicating the system corrects any deviations in the previous period at a speed of 39.2 percent annually to revert to steady state. The magnitude is similar to what was found in studies of similar countries (see Hurlin and Llorca (2017) for a sample of Central and Latin American countries and Alagidede and Tweneboah (2015) for Latin American countries). This implies a relatively slow response and is reflected in persistent fiscal imbalances in the most Caribbean countries as shown in Figure A1. Moreover, as shown in Fajgenbaum and Loser (2018) fundamental reforms to fiscal institutions including fiscal rules, fiscal limits, sovereign wealth funds and procedural rules and transparency rules to promote fiscal discipline and to adequately respond to shocks are lacking in most Caribbean countries.

The long-run coefficient of government spending is positive and highly statistically significant at all conventional levels of statistical significance, indicating that fiscal policies are consistent with their intertemporal budget constraints. The magnitude of the coefficient under the PGM estimator is 0.381 . The other two estimators produced similar magnitudes ranging from 0.329 for the MG estimator and 0.40 for the DFE estimator. This implies that a one percentage point increase in the government expenditure ratio leads to an increase in the 
government revenue ratio of 0.381 percentage points on average for the Caribbean. The magnitude of the coefficient is however much lower than that what is observed for Central and Latin American countries, which has coefficient estimates closer to unity (ranging from 0.73 to 0.95, see Alagidede and Tweneboah, 2015 and Hurlin and Llorca, 2017). This has important implications as the magnitude of the long-run coefficient on government expenditure $(\beta)$ can be used to classify fiscal sustainability as either "strong" or "weak". Following, Quintos (1995) a rejection of the null hypothesis of no-cointegration and where $\beta=1$, implies that fiscal sustainability exists in "strong" form, however, the fiscal stance is only "weakly" sustainable if $0<\beta<1$, under this weaker form of sustainability the government expenditure increases at a rate that is higher than government revenues. Based on this evidence and the classification of Quintos (1995), one can conclude that as the long-run coefficient on government expenditure for the Caribbean is less than unity, fiscal policy has been "weakly" sustainable over the period 1991-2017. In the next section, fiscal sustainability is further examined using fiscal reaction functions and controlling for other determinants of the primary balance.

Table 4. Dependent Variable: General Government Revenue

\begin{tabular}{|c|c|c|c|}
\hline Explanatory variables & PMG & MG & DFE \\
\hline \multirow[t]{2}{*}{ Government expenditure $(\hat{\beta})$} & 0.381 & 0.329 & 0.40 \\
\hline & {$[5.47]^{* * *}$} & {$[2.80] * * *$} & {$[2.39]^{* * *}$} \\
\hline \multirow[t]{2}{*}{ Error correction term $(\hat{\alpha})$} & -0.392 & -0.454 & -0.306 \\
\hline & {$[6.64]^{* * *}$} & {$[7.88] * * *$} & {$[3.45]^{* * *}$} \\
\hline \multirow[t]{2}{*}{ Expenditure (t-1) } & 0.263 & 0.267 & 0.328 \\
\hline & {$[2.99] * * *$} & {$[2.89]^{* * *}$} & {$[3.47]^{* * *}$} \\
\hline \multirow[t]{2}{*}{ Constant } & 5.726 & 7.963 & 4.40 \\
\hline & {$[6.48]^{* * *}$} & {$[4.28]^{* * *}$} & {$[2.01]^{* *}$} \\
\hline \multirow[t]{2}{*}{$\begin{array}{l}\text { Hausman test } \\
\text { (MG vs. PMG) }\end{array}$} & 0.24 & $\begin{array}{l}\text { Hausman test } \\
\text { (PMG vs. DFE) }\end{array}$ & 0.01 \\
\hline & {$[0.63]$} & & {$[0.94]$} \\
\hline
\end{tabular}

Source: Author's estimates.

Note: $* * *$ Statistically significant at the $1 \%$ level. ** Statistically significant at the $5 \%$ level. * Statistically significant at the $10 \%$ level.

\subsection{Fiscal Reaction Functions}

This section estimates a fiscal reaction function for Caribbean countries following the approach of Bohn (1998). The fiscal reaction function relates the government's primary balance to the level of debt and shows the extent to which the level of debt influences fiscal 
policy (see Bohn, 1998; 2008; Mendoza and Ostry, 2008; Celasun and Kang, 2006):

$$
p b_{t}=\tau \cdot d_{t-1}+\xi_{t}
$$

Where $p b_{t}$ is the primary balance to GDP ratio and $d_{t}$ is the government debt to GDP ratio. The parameter $\tau$ measures the responsiveness of the primary balance ratio and $\xi_{t}$ is the error term. The empirical specification above is extended below to include other economic and political factors:

$$
p b_{i t}=\alpha+\delta p b_{i, t-1}+\tau \cdot d_{i, t-1}+\sum_{i=1}^{n} \beta X_{i, t}+\theta_{i}+\gamma_{t}+\xi_{i, t}
$$

In the extended model estimation, the focus is to tackle estimation issues of endogeneity and cross-sectional correlation. In the first instance, as countries are slow to adjust fiscal policies to macroeconomic shocks, the lagged dependent variable is included in (13) to reflect the high persistence of the primary balance. The inclusion of $p b_{i, t-1}$ results in a dynamic panel regression which can cause the estimated coefficient $(\hat{\delta})$ of the lagged dependent variable to be biased (i.e. the Nickell bias) when estimated with the Least Square Dummy Variable (LSDV) or fixed effects estimators (Nickell, 1981). However, as the literature shows, the Nickell bias diminishes when the time dimension is relatively large (Nickell, 1981; Judson and Owen, 1999). The regressions in this section cover a period of 27 years which is greater than the 'rule of thumb' which suggests that $\mathrm{T}$ should be greater than 20 to address the inconsistency of the FE estimator in a dynamic panel setting (see Checherita-Westphal and Žd'árek, 2017 and EC, 2011 for application to European countries). Nevertheless, the bias-corrected LSDV estimator (LSDVC) of Bruno (2005) is used as a robustness check to account for any potential bias. The extended model also includes the output gap (difference between actual GDP and potential GDP) to control for the business cycle, and other economic and political factors such as the current account balance ratio and an election year dummy variable. The election year dummy variable takes on a value of one (1) for the year prior to a national election and the election year. Since the output gap and the current account balance ratio variables are both endogenous due to bi-directional causality with the contemporaneous primary balance, they should be instrumented. The lagged values (first and second lags) of both variables are used as instruments in the panel fixed effects instrumental variable (FE-IV) estimator (See for example Ayuso et al. 2008 and Gali and Perotti, 2004).(Note 1) The countries in the panel also share similar features such as high external dependence on either hydrocarbons and minerals or services and tourism, and relatively strong economic relations. These characteristics imply the presence of CD as shown by the Pesaran (2004) CD test in Table 5. Time fixed effects are used in the FE-IV estimator to control for these common shocks (see Jansen, 2016). Moreover, the Prais-Winsten estimator with correlated panels corrected standard errors (PCSEs) and the Driscoll-Kraay estimators are used as robustness checks for presence of cross-sectional dependence (see Prais and Winsten, 1954; Driscoll and Kraay 1998). In this regard, FE-IV is the base or preferred estimator against which other estimators mentioned above are used for robustness checks. The parameters $\theta_{i}, \gamma_{t}$, and $\xi_{i t}$ are country fixed effects, time fixed effects and the error term which captures measurement errors and random shocks. 
Table 5. Cross Section Independence (Pesaran, 2004)

\begin{tabular}{lcccc}
\hline Variables (in \% of GDP) & CD-test & P-value & Avg. (pij) & Avg. $\mid($ pij) $)$ \\
\hline Primary balance ratio & 2.05 & 0.04 & 0.06 & 0.29 \\
Debt ratio & 3.70 & 0.00 & 0.10 & 0.50 \\
Current account ratio & 2.78 & 0.00 & 0.08 & 0.34 \\
Output gap & 3.81 & 0.00 & 0.11 & 0.29 \\
\hline
\end{tabular}

Source: Author's estimates.

\subsubsection{Empirical Results}

The results from the FE-IV estimator and other estimators used for robustness are shown in Table 6. All the models include time fixed effects while some include both time fixed effects and country fixed effects. In the panel IV-FE, the output gap and the current account balance are instrumented by their first and second lagged values. The panel IV-FE estimations perform well in various robustness tests for weak instruments (Kleibergen-Paap test) and the validity of instruments (Hansen test). However, as there is a potential for bias due to the inclusion of a dynamic term, Bruno's (2005) bias corrected LSDV estimator(LSDVC) which extends Kiviet (1995) results to treat with the inclusion of a lagged dependent variable is employed. Judson and Owen (1999) showed that the LSDVC estimator is more efficient and performs better for panels with small $\mathrm{T}$ and $\mathrm{N}$ dimensions, as in our case, than other options such as the GMM estimators of Arellano and Bond (1991) or IV estimators such as Anderson and Hsiao (1982). Comparing the results from the standard OLS estimation in column 1 and the LSDVC in column 5 demonstrated that $\hat{\delta}$ is not likely to be biased, due to the relatively long time dimension.

The main coefficient of interest $\hat{\tau}$ (first lag of the debt ratio) is highly statistically significant in all empirical specifications with only a small variation between the various estimators, between 0.019 to 0.024.(Note 2) The highest coefficient is from the Driscoll-Kraay estimator which controls for both time and country fixed effects and cross sectional independence. The remaining estimators including our preferred model reports a coefficient estimate of 0.019 . Based on these estimations and robustness checks, the evidence suggests that a positive reaction of primary surpluses to higher debt: the primary balance improves by about 0.02 for every 1 percentage point increase in the debt ratio, after controlling for other factors. The other variables in the model have the expected sign, and except for the lagged (-2) current account balance in a few models are statistically significant at the 5 percent level of statistical significance. The output gap which shows a negative sign suggests some degree of procyclical of fiscal policy (for further evidence on the procyclical of fiscal policy in the Caribbean see Samuel, 2009; Araujo, 2009). The current account balance ratio is statistically significant in our preferred model when it is instrumented with its first and second lag but becomes insignificant in models that do not allow for endogeneity and the where the second lag is used. The election dummy variable is statistically significant in all specifications and vary from -0.885 to -0.982 suggesting that on average, election years (and the year prior to a national election) have a negative effect on fiscal positions in the Caribbean. 


\section{Macrothink}

Table 6. Fiscal Reaction Functions: Panel Fixed Effects-IV and Robustness Checks

\begin{tabular}{|c|c|c|c|c|c|}
\hline & $\begin{array}{l}\text { Panel } \\
\text { IV-FE }\end{array}$ & Pooled OLS & LSDVC & $\begin{array}{c}\text { Driscoll-Kraay } \\
\text { FE } \\
\end{array}$ & PCSEs \\
\hline Lagged primary balance & $\begin{array}{c}0.716 \\
{[0.063]^{* * *}}\end{array}$ & $\begin{array}{c}0.757 \\
{[0.052]^{* * *}}\end{array}$ & $\begin{array}{c}0.751 \\
{[0.054]^{* * *}}\end{array}$ & $\begin{array}{c}0.702 \\
{[0.068]^{* * *}}\end{array}$ & $\begin{array}{c}0.711 \\
{[0.050]^{* * *}}\end{array}$ \\
\hline Lagged debt & $\begin{array}{c}0.019 \\
{[0.007]^{* * *}}\end{array}$ & $\begin{array}{c}0.019 \\
{[0.005]^{* * *}}\end{array}$ & $\begin{array}{c}0.019 \\
{[0.009]^{* *}}\end{array}$ & $\begin{array}{c}0.024 \\
{[0.006]^{* * *}}\end{array}$ & $\begin{array}{c}0.019 \\
{[0.007]^{* * *}}\end{array}$ \\
\hline Current account & $\begin{array}{c}0.057 \\
{[0.044]^{* * *}}\end{array}$ & & & & \\
\hline Output gap & $\begin{array}{c}-0.230 \\
{[0.112]^{* *}}\end{array}$ & & & & \\
\hline Election dummy & $\begin{array}{c}-0.885 \\
{[0.320]^{* *}}\end{array}$ & $\begin{array}{c}-0.907 \\
{[0.309]^{* * *}}\end{array}$ & $\begin{array}{c}-0.982 \\
{[0.350]^{* * *}}\end{array}$ & $\begin{array}{c}-0.979 \\
{[0.164]^{* * *}}\end{array}$ & $\begin{array}{c}-0.952 \\
{[0.268]^{* * *}}\end{array}$ \\
\hline $\begin{array}{l}\text { Lagged current account } \\
(-2)\end{array}$ & & $\begin{array}{c}0.018 \\
{[0.021]}\end{array}$ & $\begin{array}{c}0.007 \\
{[0.031]}\end{array}$ & $\begin{array}{c}0.011 \\
{[0.027]}\end{array}$ & $\begin{array}{l}-0.006 \\
{[0.022]}\end{array}$ \\
\hline Lagged output gap (-2) & & $\begin{array}{c}-0.127 \\
{[0.051]^{* *}}\end{array}$ & $\begin{array}{c}-0.126 \\
{[0.063]^{* *}}\end{array}$ & $\begin{array}{c}-0.132 \\
{[0.037]^{* * *}}\end{array}$ & $\begin{array}{c}-0.133 \\
{[0.026]^{* * *}}\end{array}$ \\
\hline Constant & & $\begin{array}{l}-0.909 \\
{[0.735]}\end{array}$ & & $\begin{array}{c}-1.095 \\
{[0.319]^{* * *}}\end{array}$ & $\begin{array}{c}0.250 \\
{[1.098]} \\
\end{array}$ \\
\hline Number of observations & 243 & 243 & 243 & 251 & 251 \\
\hline Number of groups & 10 & 10 & 10 & 10 & 10 \\
\hline R-squared & 0.58 & 0.72 & & 0.61 & 0.76 \\
\hline Country FE & No & No & No & Yes & Yes \\
\hline Time FE & Yes & Yes & Yes & Yes & Yes \\
\hline $\begin{array}{l}\text { Kleibergen-Paap (p-val) } \\
\text { Hansen J-test ( } p \text {-value) }\end{array}$ & $\begin{array}{l}0.000 \\
0.225\end{array}$ & & & & \\
\hline
\end{tabular}

Source: Author's estimates.

Notes: $\mathrm{p}$-value: $* * * \mathrm{p}<0.01, * * \mathrm{p}<0.05, * \mathrm{p}<0.1$ : variable is statistically significant at the $1 \%, 5 \%$ and $10 \%$, respectively. Country fixed effects and time fixed effects are not reported, robust standard errors are reported.

\section{Conclusions}

Persistent fiscal imbalances and rising debt levels have emerged as perhaps the most 
important macroeconomic challenge facing Caribbean countries in the last decade. Most Caribbean countries have debt ratios that are higher than the negative debt-growth threshold of 60 percent of GDP as suggested by Greenidge et al. (2012). While some countries are undertaking reforms to strengthen their fiscal positions, relatively weak fiscal institutions, high vulnerability to exogeneous shocks, limited fiscal buffers, combined with an expenditure profile rigidly focused on non-discretionary spending can affect their ability to adjust fiscal policies in a timely manner to fiscal shocks. Within this context, this paper examined whether the fiscal behavior of Caribbean countries over the period 1991-2017 is sustainable in the long-run.

The theoretical framework employed to test the sustainability of fiscal policy is the inter-temporal budget constraint, which states that the market value of public debt must be equal to the present value of all discounted future budget surpluses. The econometric exercises were undertaken in two parts, (i) by testing for cointegration between government revenues and expenditures and (ii) estimating fiscal reaction functions to determine how Caribbean governments adjust their primary balances to increases in debt levels. The analysis tested for and treated with endogeneity and cross-sectional dependence and other relevant econometric issues using various econometric tests and estimators.

The main findings from the panel cointegration analysis indicate the presence of a long run relationship between the two fiscal variables, based on both the error-correction based panel cointegration tests of Westerlund (2007) and the residual based tests of Pedroni (1999, 2004) and Kao (1999). Nevertheless, the estimated cointegration parameter is less than one and lower than estimates found for other countries using similar methodologies, which suggests a situation of "weak" fiscal sustainability: a one percentage point increase in the government expenditure ratio leads to an increase in the government revenue ratio of 0.381 percentage points. Also, the speed of adjustment parameter indicated that the system corrects any deviations in the previous period at a speed of 39.2 percent annually to revert to steady state, similar to other countries. The fiscal reaction functions showed that the primary balance improves by about 0.02 for every 1 percentage point increase in the debt ratio, reinforcing the findings from the cointegration analysis of "weak" sustainability. This estimate is marginally lower than what is observed for European countries where the range is $0.03-0.05$ for every 1 percentage point increase in the debt-to-GDP ratio. The extended fiscal reaction functions also showed evidence that there is some degree of procyclical of fiscal policy, and national elections tend to worsen fiscal positions in the Caribbean. Taking these results together suggest that countries need to be cautious about continuing past fiscal policies into the future and seek to enact measures to ensure that they can adequately respond to fiscal-related shocks.

\section{References}

Acevedo, S., Cebotari, A., \& Turner-Jones, T. (2013). Caribbean Small States: Challenges of 
High Debt and Low Growth. Washington DC: International Monetary Fund.

Afonso, A., \& João T. J. (2012). Revisiting fiscal sustainability: panel cointegration and structural breaks in OECD countries (European Central Bank, No. 1465). https://doi.org/10.2139/ssrn.2180575

Afonso, A. (2005). Fiscal Sustainability: The Unpleasant European Case. Public Finance Analysis, 61(4), 19-44. https://doi.org/10.1628/0015221053722532

Afonso, A., \& Rault, C. (2009). What do we really know about fiscal sustainability in the EU? A panel data diagnostic. Review of World Economics, 145(4), 731-755. https://doi:10.1007/s10290-009-0034-1

Alagidede, P., \& Tweneboah G. (2015). On the Sustainability and Synchronization of Fiscal Policy in Latin America. Latin American Journal of Economics, 52(2), 213-240. http://dx.doi.org/10.7764/LAJE.52.2.213

Alleyne, T., Srinivasan, K., Ramakrishnan, U., \& Otker, I. (2018). Unleashing Growth and Strengthening Resilience in the Caribbean. Washington DC: International Monetary Fund.

Anderson, T. W., \& Hsiao, C. (1982). Formulation and estimation of dynamic models using panel data. Journal of Econometrics, 18(1), 570-606. https://doi.org/10.1016/0304-4076(82)90095-1

Araujo D. J. (2009). Fiscal Cycles in the Caribbean. IMF Working Papers 09/158. Washington DC: International Monetary Fund. http://dx.doi.org/10.5089/9781451873054.001

Arellano, M., \& Bond, S. (1991). Some Tests of Specification for Panel Data: Monte Carlo Evidence and an Application to Employment Equations. Review of Economic Studies, 58(2), 277-297. https://doi.org/10.2307/2297968

Baglioni A., \& Umberto C. (1993). Intertemporal Budget Constraint and Public Debt Sustainability: The Case of Italy. Applied Economics, 25(2), 275-283. https://doi.org/10.1080/00036849300000033

Banerjee, A., \& Carrion-i-Silvestre, J. (2017). Testing for Panel Cointegration Using Common Correlated Effects Estimators. Journal of Time Series Analysis, 38(4), 610-636. https://doi.org/10.1111/jtsa.12234

Banerjee, A., Marcellino, M., \& Osbat, C. (2004). Some cautions on the use of panel methods for integrated series of macro-economic data. Econometrics Journal, 7(2), 322-340. https://doi.org/10.1111/j.1368-423X.2004.00133.x

Banerjee, A., Marcellino, M., \& Osbat, C. (2005). Testing for PPP: should we use panel methods? Empirical $\quad$ Economics, $30(2005), \quad$ 77-91. https://doi.org/10.1007/s00181-004-0222-8

Bohn, H. (1998). The Behavior of U.S. Public Debt and Deficits. The Quarterly Journal of 
Economics, 113(3), 949-963.

Bohn, H. (2008). The Sustainability of Fiscal Policy in the United States in Sustainability of Public Debt. Cambridge, Massachusetts: MIT Press. https://doi.org/10.7551/mitpress/9780262140980.003.0002

Breitung, J. (2000). The Local Power of Some Unit Root Tests for Panel Data. In Baltagi, B. Thomas B. Fomby, \& R. Carter Hill (Ed.), Nonstationary Panels, Panel Cointegration, and Dynamic Panels. Advances in Econometrics. Amsterdam: JAI. https://doi.org/10.1016/S0731-9053(00)15002-9

Bruno, G. S. F. (2005). Approximating the bias of the LSDV estimator for dynamic unbalanced panel data models. Economics Letters, 87, 361-366. https://doi.org/10.1016/j.econlet.2005.01.005

Carrion-i-Silvestre, J. L., \& Sanso, A. (2006). Testing the null of cointegration with structural breaks. Oxford Bulletin of Economics and Statistics, 68(5), 623-646. https://doi.org/10.1111/j.1468-0084.2006.00180.x

Celasun O., \& Kang, J. (2006). On the Properties of Various Estimators for Fiscal Reaction Functions. IMF Working Papers 06/182. Washington DC: International Monetary Fund.

Checherita-Westphal, C., \& Žd'árek, V. (2017). Fiscal Reaction Function and Fiscal Fatigue: Evidence for the Euro Area. (European Central Bank, Working Paper Series, No. 2036). https://doi:10.2866/827938

Christophe E., \& Llorca, M. (2017). Fiscal Sustainability in Central and Latin America Countries: Evidence from a Panel Cointegration Approach. Economics Bulletin, 37(4), 2292-2300.

Claeys P. (2007). Sustainability of EU Fiscal Policies, a Panel Test. Journal of Economic Integration, 22(1), 112-127. https://doi.org/10.11130/jei.2007.22.1.112

Driscoll, J. C., \& Kraay, A. C. (1998). Consistent Covariance Matrix Estimation with Spatially Dependent Panel Data. Review of Economics and Statistics, 80(4), 549-560. https://doi.org/10.1162/003465398557825

Ehrhart, C., \& Llorca, M. (2007). A Global Perspective of Fiscal Sustainability: Evidence from a Panel of 20 OECD Countries. Paper presented at the 11th International Conference on Macroeconomic Analysis and International Finance in University of Crete, Rethymno, Greece. Retrieved from http://economics.soc.uoc.gr/macro/11conf/docs/Fiscal_sustainanility_OECD_countries.p df

Engle, R., \& Granger, C. (1987). Co-Integration and Error Correction: Representation, Estimation, and Testing. Econometrica, 55(2), 251-276. https://doi.org/0012-9682

European Commission (EC, 2011). Public Finances in Economic and Monetary Union. EC, Brussels, European Economy. Retrieved from 
http://ec.europa.eu/economy_finance/publications/european_economy/2011/pdf/ee-2011 -3_en.pdf

Fajgenbaum J., \& Loser, C. (2018). The Fiscal Challenges in the Caribbean and the Role for Institutions. In Diether Beuermann and Moisés Schwartz, (Ed.), Nurturing institutions for a resilient Caribbean. Washington, DC: Inter-American Development Bank. http://dx.doi.org/10.18235/0001333

Ghatak A. (2001). Structural Break: Tests of the Present-Value Government Borrowing Constraint and Stability of Debt-GDP Ratio in the UK: 1970-2000. European Research Studies Journal, IV(3-4), 37-54.

Greenidge, K., Craigwell, R., Thomas, C., \& Drakes, L. (2012). Threshold Effects of Sovereign Debt: Evidence from the Caribbean. IMF Working Paper No. 12/157. Washington DC: International Monetary Fund. http://dx.doi.org/10.5089/9781475504507.001

Hadri, K. (2000). Testing for Stationarity in Heterogeneous Panel Data. The Econometrics Journal, 3(2), 148-161. https://doi.org/10.1111/j.1368-423X.2005.00151.X

Hakkio, C., \& Rush, M. (1991). Is the Budget Deficit "Too Large? Economic Inquiry, 29(3), 429-45.

Hamilton, J. D., \& Flavin, M. A. (1986). On the Limitations of Government Borrowing: A Framework for Empirical Testing. American Economic Review, 76(4), 808-16. https://doi.org/10.3386/w1632

Hausman, J. (1978). Specification Tests in Econometrics. Econometrica, 46(6), 1251-71. https://doi.org/10.1080/07474938408800065

Hsiao C., Pesaran, H., \& Pick, A. (2012). Diagnostic Tests of Cross - section Independence for Limited Dependent Variable Panel Data Models. Oxford Bulletin of Economics and Statistics, 74(2), 253-277. https://doi.org/10.2307/1913827

Hurlin, C., \& Mignon V. (2007). Second Generation Panel Unit Root Tests. HAL Working Paper. https://halshs.archives-ouvertes.fr/halshs-00159842

Im, K. S., Pesaran, H., \& Shin, Y. (2003). Testing for unit roots in heterogeneous panels. Journal of Econometrics, $115(1), \quad$ 53-74. https://doi.org/10.1016/S0304-4076(03)00092-7

Jansen, S. (2016). Time-varying Fiscal Policy Reaction Functions. (Unpublished doctoral dissertation). University of Ghent, Ghent, Belgium.

Judson, A., \& Owen, A. (1999). Estimating Dynamic Panel Data Models: A Guide for $\begin{array}{llll}\text { Macroeconomists. } & \text { Economics } & \text { Letters, } & \text { 65(1), }\end{array}$ https://doi.org/10.1016/S0165-1765(99)00130-5

Kao, C. (1999). Spurious regression and residual-based tests for cointegration in panel data. Journal of Econometrics, 90(1), 1-44. https://doi.org/10.1016/S0304-4076(98)00023-2 
Khadan, J., \& Deonarine A. (2019). Testing the Intertemporal Budget Constraint for Small States. Economics Bulletin, 39(2), 1176-1183.

Khadan, J., \& Ruprah I., (2016). Debt: The Dark Side. Washington, DC: Inter-American Development Bank.

Kirchgaessner, G., \& Prohl, S. (2008). Sustainability of Swiss Fiscal Policy. Swiss Journal of Economics and Statistics, 144(1), 57-83. https://doi.org/10.1007/BF03399249

Kiviet, J. F. (1995). On bias, inconsistency, and efficiency of various estimators in dynamic panel data models. Journal of Econometrics, 68(1), 53-78. https://doi.org/10.1016/0304-4076(94)01643-E

Koetsier, I. (2017). The Fiscal Impact of Natural Disasters. (Utrecht School of Economics Working Paper No. 17-17). Netherlands: Utrecht University.

Kwiatkowski, D., Phillips P., Schmidt P., \& Shin Y. (1992). Testing the Null Hypothesis of Stationarity Against the Alternative of a Unit Root: How Sure Are We That Economic Time Series Have a Unit Root. Journal of Econometrics, 54(1-3), 159-178. https://doi.org/10.1016/0304-4076(92)90104-Y

Levin, A., Lin C. F., \& Chu C. S. (2002). Unit root tests in panel data: Asymptotic and finite sample properties. Journal of Econometrics, 108(1), 1-24. https://doi.org/10.1016/S0304-4076(01)00098-7

Lyhagen, J. (2008). Why Not Use Standard Panel Unit Root Test for Testing PPP. Economics Bulletin, 3(26), 1-11.

Medina, L. (2010). The Dynamic Effects of Commodity Prices on Fiscal Performance in Latin America. IMF Working Papers 10/192. Washington DC: International Monetary Fund.

Mendoza, E. G., \& Jonathan D. O. (2008). International Evidence on Fiscal Solvency: Is Fiscal Policy Responsible. Journal of Monetary Economics, 55(6), 1081-1093. https://doi.org/10.1016/j.jmoneco.2008.06.003

Nickell, S. (1981). Biases in Dynamic Models with Fixed Effects. Econometrica, 49(6), 1417-26. https://doi.org/10.2307/1911408

O'Connell, P. G. J. (1998). The Overvaluation of Purchasing Power Parity. Journal of International Economics, 44(1), 1-19. https://doi.org/10.1016/S0022-1996(97)00017-2

Pedroni, P. (1999). Critical Values for Cointegration Tests in Heterogeneous Panels with Multiple Regressors. Oxford Bulletin of Economics and Statistics, 61, 653-670. https://doi.org/10.1111/1468-0084.0610s1653

Pedroni, P. (2004). Panel Cointegration: Asymptotic and Finite Sample Properties of Pooled Time Series Tests with an Application to the PPP Hypothesis. Econometric Theory, 20(3), 597-625. https://doi.org/10.1017/S0266466604203073 
Pesaran, H. (2007). A Simple Panel Unit Root Test in the Presence of Cross Section Dependence. Journal of Applied Econometrics, 22(2), 265-312. https://doi.org/10.1002/jae.951

Pesaran, H., \& Smith, R. (1995). Estimating Long-Run Relationships from Dynamic Heterogeneous Panels. Journal of Econometrics, 68(1), 79-113. https://doi.org/10.1016/0304-4076(94)01644-F

Pesaran, H., Shin Y., \& Smith R. (1999). Pooled Mean Group Estimation of Dynamic Heterogeneous Panels. Journal of the American Statistical Association, 94(446), 621-34. https://doi.org/10.1080/01621459.1999.10474156

Phillips P., \& Sul D. (2003). The Elusive Empirical Shadow of Growth Convergence. Cowles Foundation Discussion Papers 1398. Yale University: Cowles Foundation for Research in Economics.

Phillips, P., \& Sul D. (2003). Dynamic Panel Estimation and Homogeneity Testing under Cross Section Dependence. The Econometrics Journal, 6(1), 217-259. https://doi.org/10.1111/1368-423X.00108

Prais, S. J., \& Winsten, C. B. (1954). Trend Estimators and Serial Correlation. Cowles Commission Discussion Paper No. 373. Chicago: Cowles Foundation for Research in Economics.

Quintos, C. E. (1995). Sustainability of the Deficit Process with Structural Shifts. Journal of Business and Economics Statistics, 13(4), 409-417. https://doi.org/10.2307/1392386

Ramirez A. F., \& Wright A. (2017). What are the Fiscal Limits for the Developing Economies of Central America and the Caribbean? Inter-American Development Bank Working Papers No. 8269. Washington DC: Inter-American Development Bank.

Samaké I., \& Spatafora N. (2012). Commodity Price Shocks and Fiscal Outcomes. IMF Working Papers 12/112. Washington DC: International Monetary Fund. http://dx.doi.org/10.5089/9781475503333.001

Samargandi, N., Fidrmuc J., \& Ghosh S. (2015). Is the Relationship Between Financial Development and Economic Growth Monotonic? Evidence from a Sample of Middle-Income Countries. World Development, 68(C), 66-81. https://doi.org/10.1016/j.worlddev.2014.11.010

Samuel, W. (2009). Cyclicality and Fiscal Policy in the Caribbean. Business, Finance and Economics in Emerging Economies, 4(2), 347-70.

Vilalta, D. (2015). The Composition of Fiscal Adjustments: Economic and Social Implications. Undergraduate Economic Review, 12(1), 1-33. http://digitalcommons.iwu.edu/uer/vol12/iss1/18

Villafuerte, M., Lopez-Murphy P., \& Ossowski R. (2010). Riding the Roller Coaster: Fiscal Policies of Non-renewable Resource Exporters in Latin America and the Caribbean. 


\section{IIMacrothink}

IMF Working Papers 10/251. Washington DC: International Monetary Fund. https://doi.org/10.5089/9781455209514.001

Westerlund J., \& Prohl S. (2010). Panel cointegration tests of the sustainability hypothesis in rich OECD countries. Applied Economics, 42(11), 1355-1364. https://doi.org/10.1080/00036840701721323

Westerlund, J. (2007). Testing for Error Correction in Panel Data. Oxford Bulletin of $\begin{array}{llll}\text { Economics } & \text { and }\end{array}$ https://doi.org/10.1111/j.1468-0084.2007.00477.x

\section{Notes}

Note 1. The US output gap, potential GDP growth rates and real oil price index were considered as potential instruments but were found to be inadequate.

Note 2. Empirical studies have found that the size of the reaction parameter $\tau$ varies between 0.01 and 0.10 (for a summary of the literature see Checherita-Westphal and Žd'árek, 2017).

\section{Appendix 1}

Table A1. Correlation matrix

\begin{tabular}{lccccccc}
\hline & $\begin{array}{c}\text { Debt } \\
\text { ratio }\end{array}$ & $\begin{array}{c}\text { Revenue } \\
\text { ratio }\end{array}$ & $\begin{array}{c}\text { Expenditure } \\
\text { ratio }\end{array}$ & $\begin{array}{c}\text { Current } \\
\text { account } \\
\text { ratio }\end{array}$ & $\begin{array}{c}\text { Output } \\
\text { gap }\end{array}$ & $\begin{array}{c}\text { Primary } \\
\text { balance }\end{array}$ & $\begin{array}{c}\text { Fiscal } \\
\text { balance }\end{array}$ \\
\hline Debt ratio & 1.000 & & & & & & \\
Revenue ratio & 0.367 & 1.000 & & & & & \\
Expenditure ratio & 0.520 & 0.798 & 1.000 & & & & \\
Current account ratio & -0.347 & 0.008 & -0.175 & 1.000 & & & \\
Output gap & -0.065 & 0.083 & 0.031 & 0.024 & 1.000 & & \\
Primary balance & 0.215 & 0.329 & -0.151 & 0.262 & 0.053 & 1.000 & \\
Fiscal balance & -0.275 & 0.244 & -0.389 & 0.294 & 0.078 & 0.747 & 1.000 \\
\hline
\end{tabular}

Source: Author's estimates from World Economic Outlook, October 2018. 


\section{Appendix 2}

Figure A1. Selected fiscal variables for 2000-2017
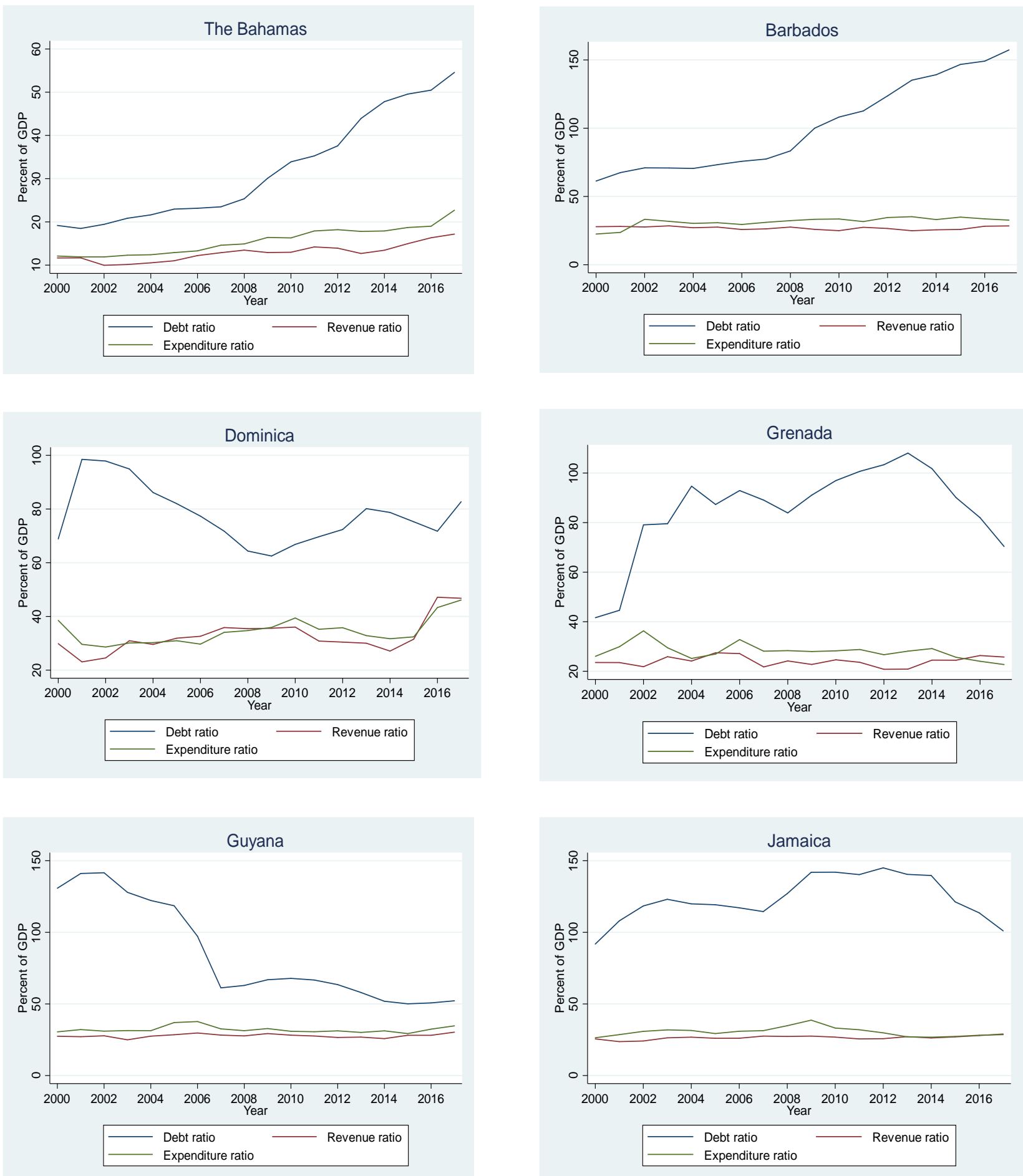

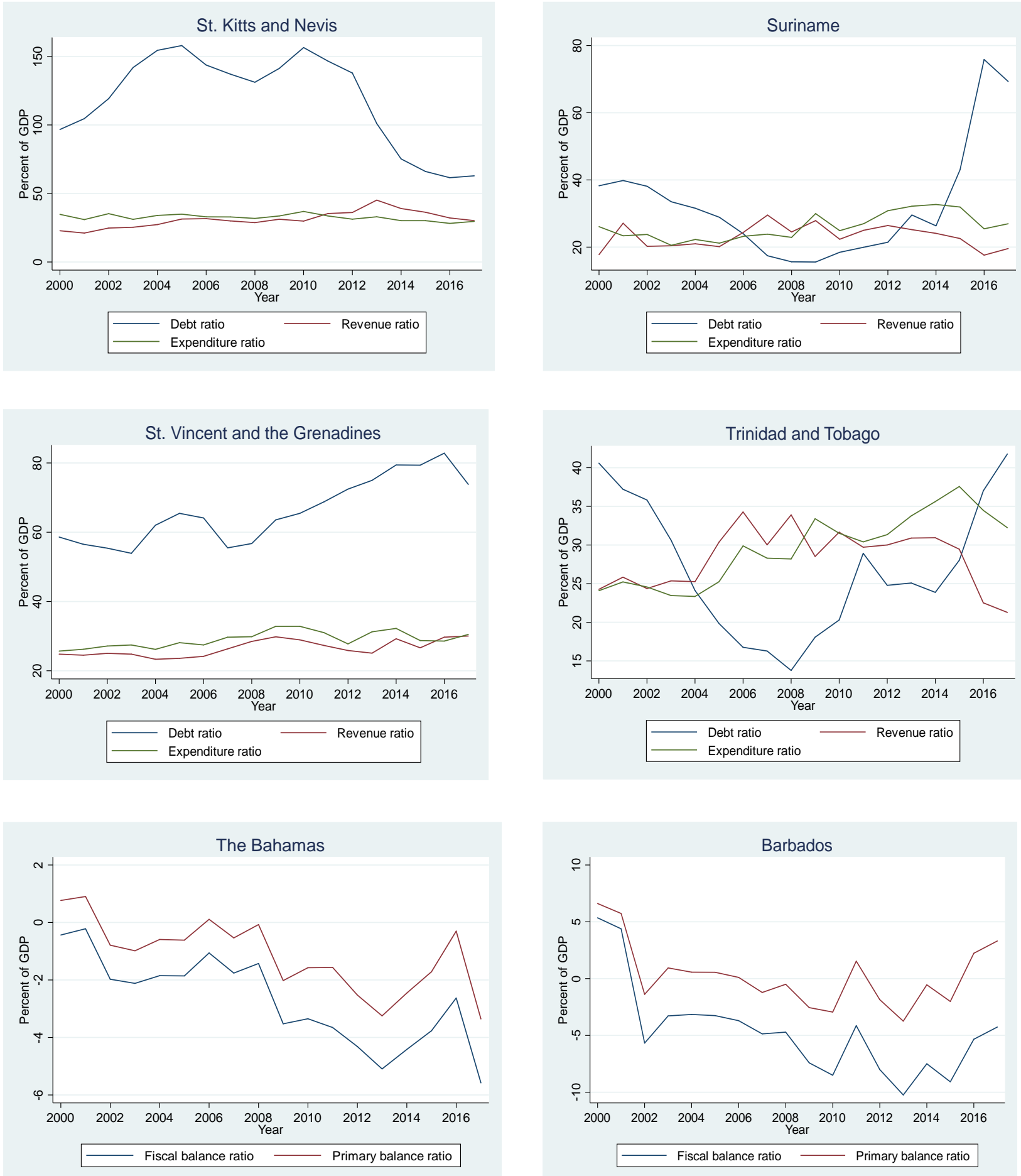

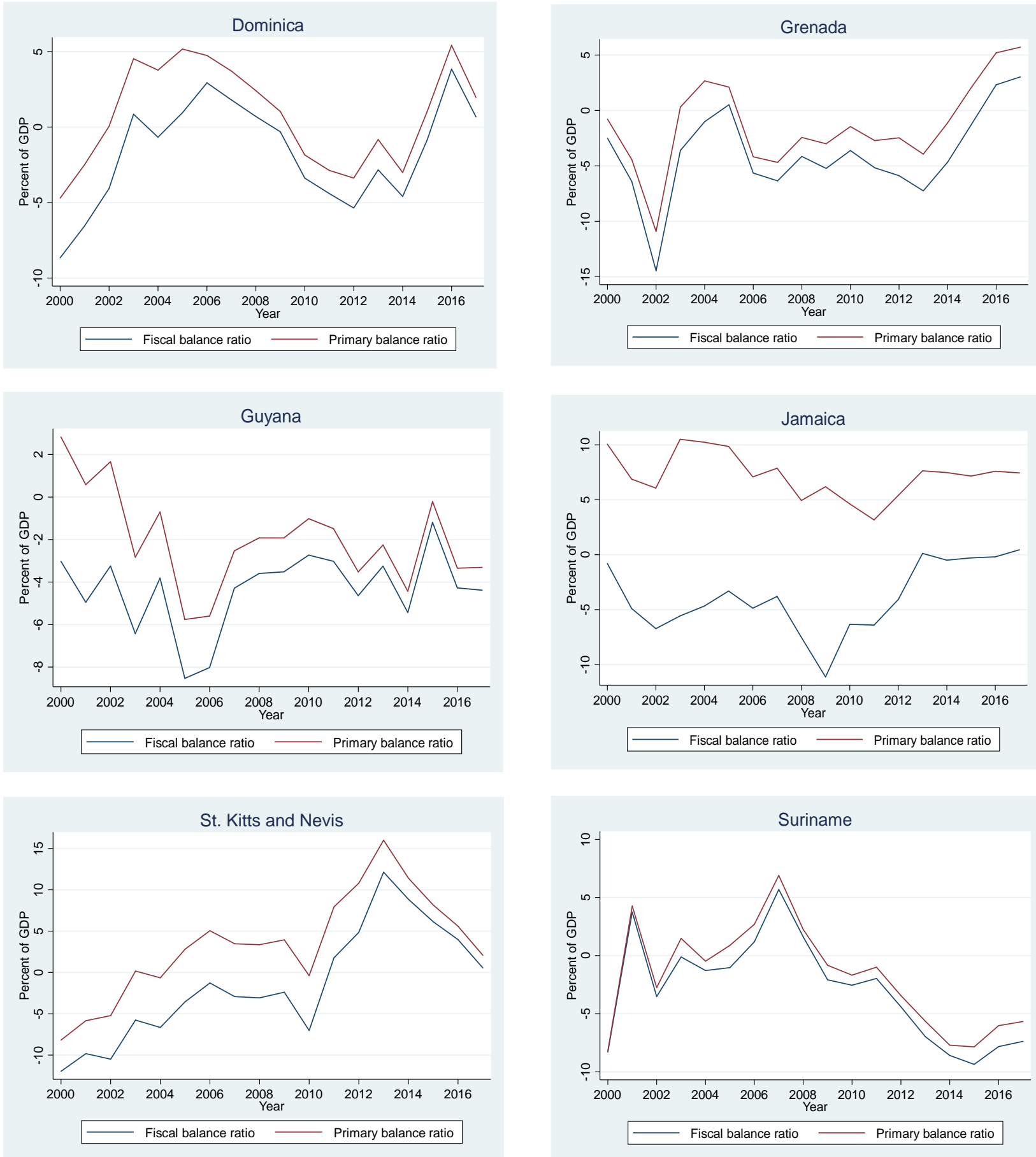

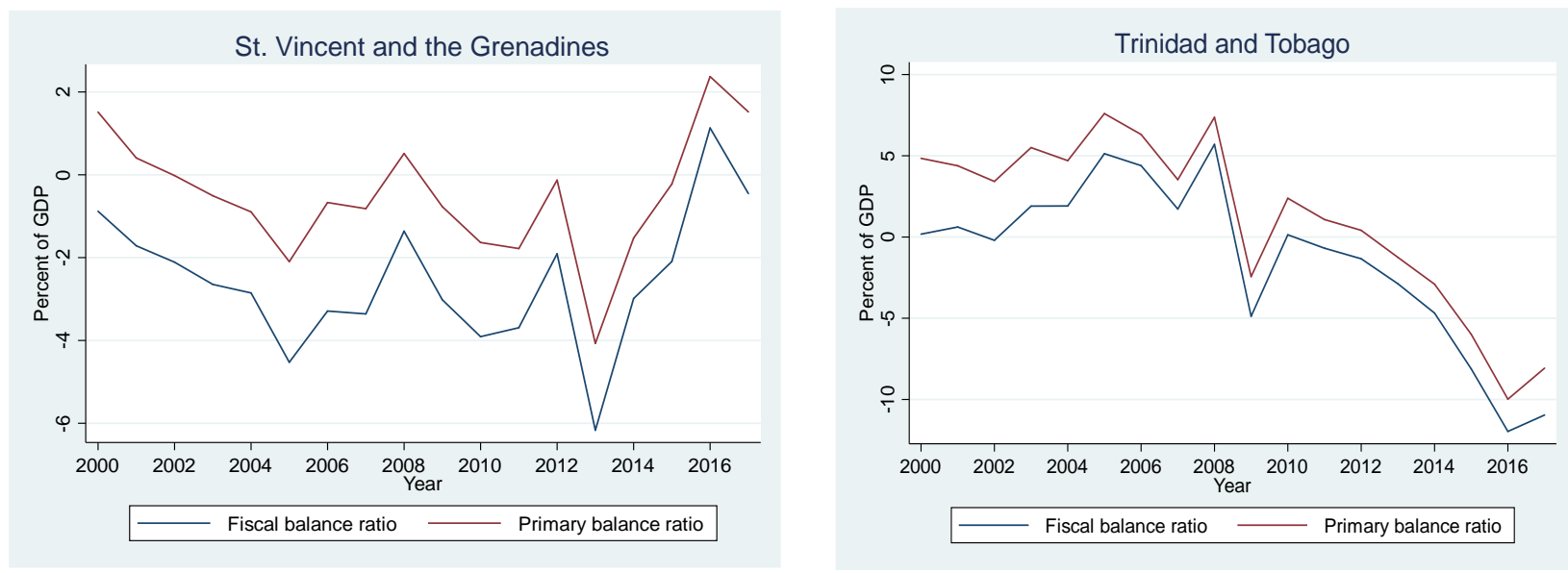

Source: World Economic Outlook, October 2018.

\section{Copyright Disclaimer}

Copyright for this article is retained by the author(s), with first publication rights granted to the journal.

This is an open-access article distributed under the terms and conditions of the Creative Commons Attribution license (http://creativecommons.org/licenses/by/3.0/). 